\title{
IGF2BP3 (IMP3) expression in angiosarcoma, epithelioid hemangioendothelioma, and benign vascular lesions
}

\author{
Misuzu Okabayshi ${ }^{1}$, Tatsuki R. Kataoka ${ }^{1 *}$, Marina Oji ${ }^{1}$, Satoko Mibayashi ${ }^{1}$, Kentaro Odani ${ }^{1}$, Atsushi Otsuka ${ }^{2}$ and \\ Hironori Haga ${ }^{1}$
}

\begin{abstract}
Background: Insulin-like growth factor-2 messenger RNA-binding protein 3 (IGF2BP3 or IMP3) is an oncofetal protein that is expressed in various cancer types, and its expression is often associated with poor prognosis. IGF2BP3 expression has not been fully settled in vascular lesions.

Methods: We evaluated the expression of IGF2BP3 in malignant (angiosarcoma and epithelioid hemangioendothelioma $[E H E]$ ) and benign (hemangioma, granulation tissue cappilaries, and pyogenic granuloma) vascular lesions using immunohistochemistry. IGF2BP3 expression was scored as negative ( $0 \%$ of endothelial/neoplastic cells), equivocal $(1-25 \%)$, or positive (> 26\%).

Results: Eight of 30 (26.7\%) cases of angiosarcoma and two of five (40\%) cases of epithelioid hemangioendothelioma were positive for IGF2BP3. In contrast, hemangiomas (10 cases) and granulation tissue capillaries (12 cases) were all negative for IGF2BP3, and some cases of pyogenic granuloma (six of 14 cases) was scored as equivocal. In angiosarcoma, IGF2BP3 expression was independent of age, gender, location, morphological pattern, prognosis, presence of metastatic foci, and PD-L1 expression.
\end{abstract}

Conclusions: IGF2BP3 is a useful marker to distinguish between malignant and benign vascular lesions.

Keywords: Angiosarcoma, Epithelioid hemangioendothelioma, Immunohistochemistry, IGF2BP3

\section{Introduction}

IGF2BP3 is an oncofetal protein that is highly expressed in fetal tissue and gonads but is rarely found in other adult benign tissues [1]. IGF2BP3 is expressed in a variety of carcinomas and sarcomas [2-8]. Among sarcomas, leiomyosarcoma and chondrosarcoma express IGF2BP3, whereas their benign counterparts, leiomyoma and chondroma, are negative $[3,5]$. One previous report showed

\footnotetext{
* Correspondence: trkata@kuhp.kyoto-u.ac.jp; trkataoka@yahoo.co.jp 'Department of Diagnostic Pathology, Kyoto University Hospital, Sakyo-ku, Kyoto 606-8507, Japan

Full list of author information is available at the end of the article
}

that two of five cases $(40 \%)$ of angiosarcoma were positive for IGF2BP3 in tissue microarray samples [8].

Angiosarcoma is a malignant tumor of vascular endothelial origin and is associated with poor prognosis [9]. The tumor cells are immunohistochemically positive for vascular markers such as CD31, CD34, ERG, and podoplanin [10]. Surgery is the most common approach to treat angiosarcoma, and achieving surgically negative margins improves prognosis $[11,12]$. Therefore, accurate evaluation of surgical margins is essential for management of cutaneous angiosarcoma patients. However, it is sometimes difficult to evaluate the surgical margins

C C The Author(s). 2020 Open Access This article is licensed under a Creative Commons Attribution 4.0 International License, which permits use, sharing, adaptation, distribution and reproduction in any medium or format, as long as you give appropriate credit to the original author(s) and the source, provide a link to the Creative Commons licence, and indicate if changes were made. The images or other third party material in this article are included in the article's Creative Commons licence, unless indicated otherwise in a credit line to the material. If material is not included in the article's Creative Commons licence and your intended use is not permitted by statutory regulation or exceeds the permitted use, you will need to obtain permission directly from the copyright holder. To view a copy of this licence, visit http://creativecommons.org/licenses/by/4.0/ The Creative Commons Public Domain Dedication waiver (http://creativecommons.org/publicdomain/zero/1.0/) applies to the data made available in this article, unless otherwise stated in a credit line to the data. 
Table 1 Details of patients

\begin{tabular}{|c|c|c|c|c|c|c|c|}
\hline \multicolumn{8}{|c|}{ (A) Angiosarcomas } \\
\hline Case & Gender & Age & Site & Lesion & Morphology & PD-L1 staining & IGF2BP3 (IMP3) staining pattern \\
\hline 1 & $\mathrm{~F}$ & 25 & Soft tissue & Metastasis & Well & Negative & Positive \\
\hline 2 & M & 61 & Skin & Local recurrence & Spindle & Negative & Positive \\
\hline 3 & $\mathrm{~F}$ & 65 & Skin & Local recurrence & Epithelioid & Negative & Positive \\
\hline 4 & M & 70 & Skin & Primary & Well & Positive & Positive \\
\hline 5 & M & 77 & Skeletal muscle & Primary & Epithelioid & Positive & Positive \\
\hline 6 & M & 80 & Skin & Local recurrence & Well & Negative & Positive \\
\hline 7 & M & 93 & Skin & Local recurrence & Well & Negative & Positive \\
\hline 8 & $\mathrm{~F}$ & 29 & Soft tissue & Primary & Spindle & Negative & Positive \\
\hline 9 & M & 32 & Heart & Primary & Spindle & Negative & Equivocal \\
\hline 10 & M & 42 & Soft tissue & Metastasis & Spindle & Negative & Equivocal \\
\hline 11 & $\mathrm{~F}$ & 59 & Subcutis & Metastasis & Epithelioid & Positive & Equivocal \\
\hline 12 & $\mathrm{~F}$ & 59 & Skin & Primary & Spindle & Negative & Equivocal \\
\hline 13 & $\mathrm{~F}$ & 63 & Skin & Local recurrence & Spindle & Positive & Equivocal \\
\hline 14 & $\mathrm{~F}$ & 64 & Breast & Primary & Epithelioid & Negative & Equivocal \\
\hline 15 & M & 66 & Skin & Local recurrence & Well & Negative & Equivocal \\
\hline 16 & M & 70 & Skin & Primary & Well & Negative & Equivocal \\
\hline 17 & M & 70 & Skin & Primary & Spindle & Negative & Equivocal \\
\hline 18 & M & 73 & Subcutis & Primary & Well & Positive & Equivocal \\
\hline 19 & M & 75 & Skin & Primary & Well & Positive & Equivocal \\
\hline 20 & $\mathrm{~F}$ & 77 & Soft tissue & Primary & Spindle & Negative & Equivocal \\
\hline 21 & M & 82 & Skin & Primary & Well & Negative & Equivocal \\
\hline 22 & M & 83 & Skin & Local recurrence & Well & Negative & Equivocal \\
\hline 23 & $\mathrm{~F}$ & 84 & Skin & Local recurrence & Epithelioid & Positive & Equivocal \\
\hline 24 & $\mathrm{~F}$ & 87 & Skin & Primary & Well & Negative & Equivocal \\
\hline 25 & M & 88 & Skin & Primary & Well & Negative & Equivocal \\
\hline 26 & $\mathrm{~F}$ & 65 & Skin & Primary & Well & Negative & Negative \\
\hline 27 & M & 75 & Kidney & Primary & Spindle & Negative & Negative \\
\hline 28 & M & 78 & Skin & Local recurrence & Well & Negative & Negative \\
\hline 29 & M & 86 & Skin & Primary & Well & Positive & Negative \\
\hline 30 & $\mathrm{~F}$ & 87 & Skin & Primary & Spindle & Negative & Negative \\
\hline
\end{tabular}

(B) Epithelioid hemangioendotheliomas

$\begin{array}{cllll}\text { Case } & \text { Gender } & \text { Age } & \text { Site } & \text { IGF2BP3 (IMP) } \\ 1 & \text { M } & 23 & \text { Cerebrum } & \text { Positive } \\ 2 & \text { M } & 81 & \text { Soft tissue } & \text { Positive } \\ 3 & \text { M } & 27 & \text { Bone } & \text { Equivocal } \\ 4 & \text { M } & 65 & \text { Esophagus } & \text { Equivocal } \\ 5 & \text { F } & 33 & \text { Liver } & \text { Negative }\end{array}$

(C) Hemangiomas

$\begin{array}{clll}\text { Case } & \text { Gender } & \text { Age } & \text { Site } \\ 1 & F & 42 & \text { Lung } \\ 2 & \text { F } & 45 & \text { Skin } \\ 3 & \text { M } & 58 & \text { Skin } \\ 4 & \text { F } & 64 & \text { Skin }\end{array}$

\section{IGF2BP3 (IMP3) staining pattern}

Negative

Negative

Negative

Negative 
Table 1 Details of patients (Continued)

\begin{tabular}{lllll}
\hline 5 & M & 69 & Skin & Negative \\
6 & F & 69 & Soft tissue & Negative \\
7 & F & 80 & Soft tissue & Negative \\
8 & M & 80 & Tongue & Negative \\
9 & M & 82 & Skin & Negative \\
10 & M & 85 & Skin & Negative
\end{tabular}

(D) Pyogenic granuloma

$\begin{array}{cllll}\text { Case } & \text { Gender } & \text { Age } & \text { Site } & \text { IGF2BP3 (I } \\ 1 & \text { F } & 30 & \text { Lip } & \text { Equivocal } \\ 2 & \text { F } & 63 & \text { Skin } & \text { Equivocal } \\ 3 & \text { M } & 65 & \text { Nasal cavity } & \text { Equivocal } \\ 4 & \text { M } & 65 & \text { Skin } & \text { Equivocal } \\ 5 & \text { M } & 65 & \text { Skin } & \text { Equivocal } \\ 6 & \text { M } & 78 & \text { Tongue } & \text { Equivocal } \\ 7 & \text { M } & 33 & \text { Skin } & \text { Negative } \\ 8 & \text { F } & 42 & \text { Soft tissue } & \text { Negative } \\ 9 & \text { M } & 48 & \text { Skin } & \text { Negative } \\ 10 & \text { M } & 66 & \text { Skin } & \text { Negative } \\ 11 & \text { M } & 66 & \text { Skin } & \text { Negative } \\ 12 & M & 67 & \text { Skin } & \text { Negative } \\ 13 & \text { M } & 75 & \text { Tongue } & \text { Negative } \\ 14 & \text { M } & 78 & \text { Skin } & \text { Negative }\end{array}$

(E) Granulation tissue

\begin{tabular}{cllll} 
Case & Gender & Age & Site & IGF2BP3 (IMP3) staining pattern \\
1 & $F$ & 34 & Skin & Negative \\
2 & F & 41 & Skin & Negative \\
3 & F & 46 & Skin & Negative \\
4 & F & 51 & Skin & Negative \\
5 & M & 57 & Skin & Negative \\
6 & M & 60 & Skin & Negative \\
7 & F & 68 & Soft tissue & Negative \\
8 & M & 74 & Subcutis & Negative \\
9 & M & 75 & Buccal mucosa & Negative \\
10 & F & 80 & Skin & Negative \\
11 & F & 82 & Lip & Negative \\
12 & M & 86 & Mandible & Negative \\
\hline
\end{tabular}

because there is no immunohistochemical marker to distinguish malignant vasoformative cells from reactive capillary vessels.

The aim of this study was to determine whether insulin-like growth factor-2 mRNA binding protein 3 (IGF2BP3 or IMP3) could be such a marker. Here, we examined 30 cases of angiosarcoma to determine whether IGF2BP3 could be a useful diagnostic marker by comparing its expression in various types of vascular lesions.

\section{Materials and methods}

\section{Pathological specimens}

We selected all the examined cases which had been fixed in $4 \%$ neutral buffered formalin for $12-72 \mathrm{~h}$ at room temperature and embedded in paraffin for this study. All selected cases were diagnosed between 2010 and 2019 . Under this condition, 30 cases of angiosarcoma and five cases of epithelioid hemangioendothelioma (EHE) were identified in the diagnostic database of Kyoto University Hospital. For comparison, benign vascular lesions (10 


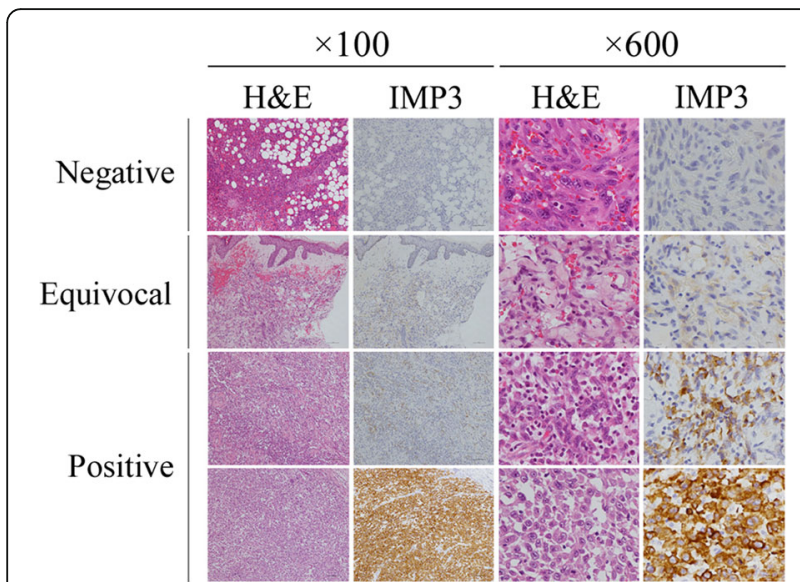

Fig. 1 IGF2BP3 (IMP3) is expressed in some pathological samples of angiosarcoma; four representative cases are presented here. Immunohistochemistry $(\times 100$ and $\times 600)$

hemangiomas, 14 pyogenic granulomas, and 12 granulation tissues with proliferating capillaries) were selected from the most recent diagnostic sign-out cases under the same fixation condition. The clinical information is summarized in Table 1. All samples Patients signed the "Kyoto University Hospital Informed Consent Form for the Non-therapeutic Use of Histopathological Materials", and signed forms were uploaded into each electronic health record.

\section{Immunohistochemical analysis}

Three-micrometer tissue sections were deparaffinized with xylene, rehydrated, and pretreated with $0.3 \%$ hydrogen peroxide for $5 \mathrm{~min}$. For IGF2BP3 staining, after steam heating the sections for $20 \mathrm{~min}$ in $\mathrm{pH} 9.0$ EDTA buffer, anti-IMP3 antibody (Ab; 1:75, mouse monoclonal clone 69.1, DAKO Cytomation, Glostrup, Denmark) was added and the sections were incubated for $15 \mathrm{~min}$ at room temperature following blocking of background staining using Protein Block (X0909; DAKO Cytomation). Staining was performed using a BOND III automated stainer (Leica Biosystems, Richmond, IL, USA) according to the manufacturer's instructions. For PD-L1 staining, after steam heating the sections for $60 \mathrm{~min}$ in pH 8.5 citrate buffer, anti-PD-L1 Ab (1:200, rabbit monoclonal clone E1L3N, Cell Signaling Technology, Beverly, MA, USA) was added and the sections were incubated for $16 \mathrm{~min}$ at room temperature following blocking of background staining using Protein Block. Staining was performed using a Benchmark Ultra automated stainer (Ventana Medical Systems, AZ, USA) according to the manufacturer's instructions. Stained sections were imaged under a BX45 microscope (Olympus, Tokyo, Japan) equipped with a DP26 digital camera (Olympus).

The degree of IGF2BP3 staining was scored, according to the proportion of the staining and regardless of the intensity of the staining as follows: negative $(0 \%$ positive among endothelial/neoplastic cells), equivocal (1-25\% positive), and positive (>26\%). PD-L1 staining was defined as positive if $>5 \%$ of membranous expression was observed at the tumor site, as reported previously [13].

\section{Statistical analysis}

Differences between groups were examined for statistical significance using Student's $t$-test or Chi-squared test (Microsoft Excel, Redmond, WA, USA). A $P$ value less than 0.05 indicated statistical significance.

\section{Results}

\section{Expression of IGF2BP3 in angiosarcoma}

IGF2BP3 staining was positive in eight of 30 angiosarcoma cases (26.6\%; Table 1a and Fig. 1). Most cases $(n=17,56.6 \%)$ were scored as equivocal (Table 1a and Fig. 1). Completely negative staining was seen in five cases (16.6\%; Table 1a and Fig. 1). There was no difference in clinical parameters (age, gender, location, morphological classification, presence of metastatic foci, and local recurrence) between IGF2BP3-positive and equivocal /-negative cases (Table 2).

Next, we assessed the association between IGF2BP3 expression and PD-L1 expression, which is a positive prognostic marker for angiosarcoma [13]. Among IGF2BP3positive cases of angiosarcoma, two cases $(25.0 \%)$ were PD-L1-negative and six (75.0\%) were PD-L1-positive.

Table 2 Summary of clinical parameters of angiosarcomas

\begin{tabular}{|c|c|c|c|c|}
\hline & IGF2BP3 (IMP3)-positive $(n=8)$ & IGF2BP3 (IMP3)-equivocal or -negative $(n=22)$ & Total $(n=30)$ & $P$ value \\
\hline Age (y.o.) & $71.1(25-93)$ & $67.9(32-88)$ & $70.3(25-93)$ & $0.64^{*}$ \\
\hline Gender (F:M) & $5: 3$ & 13:9 & $18: 12$ & $0.87^{* *}$ \\
\hline Location (Skin vs Non-skin) & $5: 3$ & $15: 7$ & 20:10 & $0.77^{* *}$ \\
\hline Morphology (Well vs Non-well) & $4: 4$ & $11: 11$ & 15:15 & $1.00^{* *}$ \\
\hline Metastatic foci (Present vs Absent) & $2: 6$ & $5: 17$ & $7: 23$ & $0.90^{* *}$ \\
\hline Local recurrence (Present vs Absent) & $4: 4$ & $8: 14$ & $12: 18$ & $0.50^{* *}$ \\
\hline PD-L1 staning (Positive vs Negative) & $2: 6$ & $6: 16$ & $8: 18$ & $0.83^{* *}$ \\
\hline
\end{tabular}

*: Student's $t$-test

**: Chi-squared tests 


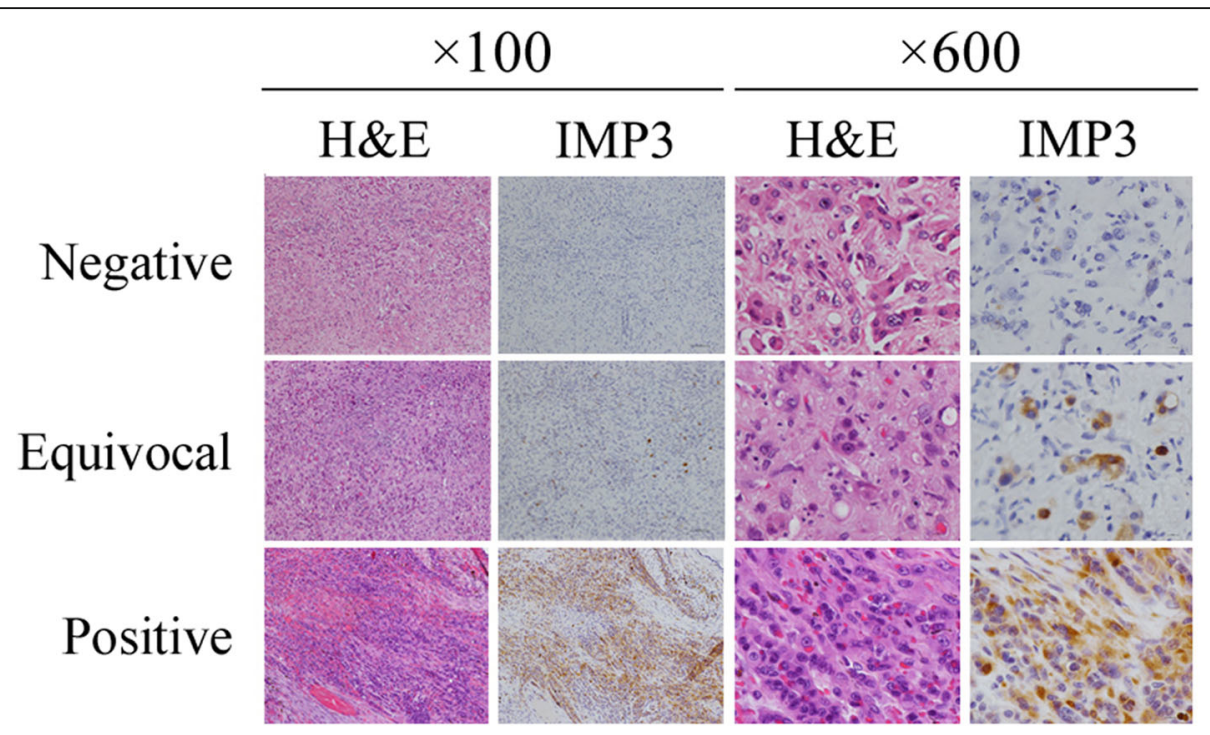

Fig. 2 IGF2BP3 (IMP3) is expressed in some pathological samples of epithelioid hemangioendothelioma; three representative cases are presented here. Immunohistochemistry ( $\times 100$ and 600)

Among negative or equivocal cases, one was a consultation from another hospital and no extra glass slide was available for PD-L1 analysis. Therefore, we assessed 21 angiosarcoma cases scored as negative or equivocal; four cases (19.0\%) were PD-L1-negative and 17 (81.0\%) were PD-L1-positive. Again, there was no statistical association between IGF2BP3 expression and PD-L1 expression among the angiosarcoma cases (Table 2).

\section{Expression of IGF2BP3 in epithelioid hemangioendothelioma (EHE)}

Two of five (40\%) cases of EHE were scored as positive for IGF2BP3 (Table 1b and Fig. 2). The remaining cases were equivocal $(n=2)$ or negative $(n=1)$ (Table $1 \mathrm{~b}$ and Fig. 2$)$.

\section{Expression of IGF2BP3 in benign vascular lesions}

No benign vascular lesion $(n=36)$ was scored as positive (Tables 1c - e and Fig. 3). Ten hemangioma cases and 14 granulation tissues showed completely negative staining (Tables 1c and e and Fig. 3). In contrast, six of 14 cases of pyogenic granuloma (42.9\%) were scored as equivocal (Table 1d and Fig. 3).

\section{Discussion}

IGF2BP3 (IMP3) is expected to be a marker to distinguish between malignant and benign lesions [2-8]. Here, we examined whether IGF2BP3 could distinguish between malignant and benign vascular lesions. We found eight of 30 angiosarcoma cases were positive for IGF2BP3, compatible with the previous study showing two of five cases of angiosarcoma were positive for IGF2BP3 in tissue microarray samples $(26.7 \%$ vs $40.0 \%$, $p=0.54$ ) [8]. In addition, two of five (40\%) cases of EHE were positive for IGF2BP3. In contrast to angiosarcoma and EHE, benign vascular lesions were all negative or equivocal for IGF2BP3. These results seem to show that IGF2BP3-positive vascular lesions are malignant, therefore the presence of IGF2BP3-positive vasoformative cells on the surgical margins of angiosarcoma and EHE should be judged as "margin positive", and the followed additional resection. However, the utility of IGF2BP3 staining would be limited, because the majority of angiosarcoma and EHE cases are negative or equivocal for IGF2BP3.

The current study shows that benign vascular lesions, including hemangioma and granulation tissue, were negative for IGF2BP3. Surprisingly, some pyogenic granuloma samples were equivocal for IGF2BP3. Recently, pyogenic granuloma samples were reported to harbor BRAF and RAS mutations, suggesting that this

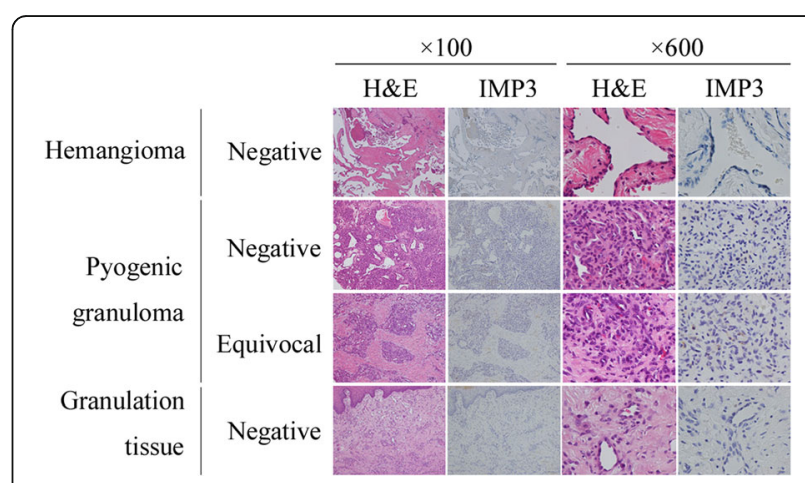

Fig. 3 IGF2BP3 (IMP3) is negative or equivocally expressed in pathological samples of benign vascular lesions; four representative cases are presented here. Immunohistochemistry $(\times 100$ and $\times 600)$ 
may be a vascular tumor [14]. IGF2BP3-positive pyogenic granuloma might be associated with the presence of such mutations. IGF2BP3-equivocal stains were also observed in angiosarcoma (17 of 30 cases, 56.7\%) and EHE (two of five cases, 40.0\%). Further study will be necessary to determine the significance of the equivocal staining.

Here, we found that low proportions $(<3 \%)$ of nonneoplastic vascular cells, including benign vascular lesions, stained positive for IGF2BP3 (data not shown). IGF2BP3 is expressed in both malignant cells and nonneoplastic adult tissues such as germinal centers of lymphoid tissue [15]. In addition, IGF2BP3 expression is correlated with the aggressiveness or proliferative phenotypes of lymphoma [15-18]. IGF2BP3 is expressed in actively proliferating cells, whether neoplastic or nonneoplastic. In the current study, the proportion of IGF2BP3-positive cells was higher in neoplastic cells than in non-neoplastic lesions. To utilize IGF2BP3 staining as a marker for malignancy, the proportion of IGF2BP3 positivity in the examined lesions should be evaluated.

IGF2BP3 plays important roles in the RNA stabilization and translation of certain genes, including matrix metalloprotease (MMP)-9, high mobility group AT-hook 2 (HMGA2), and CD44 [19-21]. MMP9 and HMGA2 are associated with cell invasion and migration. IGF2BP3 promotes trophoblast invasion and migration via MMP9 mRNA stabilization and translation [19], and melanoma invasion and migration via HMGA2 mRNA stabilization and translation [20]. IGF2BP3 might promote angiosarcoma or EHE cell invasion and migration via the same mechanisms. CD44 is a cancer stem cell marker whose expression is correlated with pathogenesis in vascular tumors [21]. IGF2BP3 might also be correlated with the pathogenesis of vascular tumors via CD44 mRNA stabilization and translation.

\section{Conclusion}

IGF2BP3 is a unique marker, indicating the vascular lesions as malignant when endothelial/neoplastic cells show positive by immunohistochemistry. We confirmed that most adult tissues were negative for IGF2BP3 and some actively proliferating vascular cells show equivocal expression. Further study will be necessary to determine the significance of the equivocal staining. Although sensitivity is not always high, IGF2BP3 can be a supplemental marker to recognize tumor cells in small biopsy specimens or tumor cut end for malignant vascular neoplasm.

\section{Abbreviations}

Ab: Antibody; EHE: Epithelioid hemangioendothelioma; IGF2BP3: Insulin-like growth factor-2 messenger RNA-binding protein 3; HMGA2: High mobility group AT-hook 2; MMP: Matrix metalloprotease

\section{Acknowledgments}

The authors thank Ms. ljiri K (Department of Diagnostic Pathology, Kyoto University Hospital, Kyoto, Japan) for her secretarial assistance.

\section{Authors' contributions}

Tatsuki R. Kataoka and Hironori Haga conceived and designed the study, and wrote, edited and reviewed the manuscript. Misuzu Okabayashi researched and analysed data, and wrote, edited and reviewed the manuscript. Marina Oji, Satoko Mibayashi, Kentaro Odani, Atsushi Otsuka researched and analysed data, and reviewed the manuscript. All authors gave final approval for publication. Tatsuki R. Kataoka takes full responsibility for the work as a whole, including the study design, access to data and the decision to submit and publish the manuscript.

\section{Authors' information}

Not applicable.

\section{Funding}

This study was financially supported by a grant from JSPS KAKENHI (18 K07014).

Availability of data and materials

Is available upon request from the corresponding author.

\section{Ethics approval and consent to participate}

Patients signed the "Kyoto University Hospital Informed Consent Form for the Non-therapeutic Use of Histopathological Materials", and signed forms were uploaded into each electronic health record. Clinical data and samples were used with the approval of the Institutional Review Board of Kyoto University Hospital.

\section{Consent for publication}

All authors consent for publication.

\section{Competing interests}

The authors declare that they have no competing interests.

\section{Author details}

1Department of Diagnostic Pathology, Kyoto University Hospital, Sakyo-ku, Kyoto 606-8507, Japan. ${ }^{2}$ Translational Research Department for Skin and Brain Diseases, Department of Dermatology, Kyoto University Hospital, Kyoto, Japan.

Received: 27 November 2019 Accepted: 19 March 2020

Published online: 23 March 2020

\section{References}

1. Lederer M, Bley N, Schleifer C, Hüttelmaier S. The role of the oncofetal IGF2 mRNA-binding protein 3 (IGF2BP3) in cancer. Semin Cancer Biol. 2014;29:3-12.

2. Do SI, Kim YW, Park HR, Park YK. Expression of insulin-like growth factor-ll mRNA binding protein 3 (IMP3) in osteosarcoma. Oncol Res. 2008;17(6):269-72.

3. Cornejo K, Shi M, Jiang Z. Oncofetal protein IMP3: a useful diagnostic biomarker for leiomyosarcoma. Hum Pathol. 2012;43(10):1567-72.

4. Yamamoto H, Arakaki K, Morimatsu K, Zaitsu Y, Fujita A, Kohashi K, Hirahashi M, Motoshita J, Oshiro Y, Oda Y. Insulin-like growth factor II messenger RNA-binding protein 3 expression in gastrointestinal mesenchymal tumors. Hum Pathol. 2014;45(3):481-7.

5. Shooshtarizadeh T, Nazeri A, Zare-Mirzaie A, Movahedinia S. Expression of insulin-like growth factor II mRNA binding protein 3 (IMP3) in enchondroma and chondrosarcoma. Pathol Res Pract. 2016;212(4):335-9.

6. Bellezza G, Prosperi E, Del Sordo R, Colella R, Rulli A, Sidoni A. IMP3 is strongly expressed in malignant Phyllodes tumors of the breast: an Immunohistochemical study. Int I Surg Pathol. 2016;24(1):37-42.

7. Takizawa K, Yamamoto H, Taguchi K, Ohno S, Tokunaga E, Yamashita N, Kubo M, Nakamura M, Oda Y. Insulin-like growth factor II messenger RNAbinding protein-3 is an indicator of malignant phyllodes tumor of the breast. Hum Pathol. 2016:55:30-8.

8. Burdelski C, Jakani-Karimi N, Jacobsen F, Möller-Koop C, Minner S, Simon R, Sauter G, Steurer S, Clauditz TS, Wilczak W. IMP3 overexpression occurs in various important cancer types and is linked to aggressive tumor features: a 
tissue microarray study on 8,877 human cancers and normal tissues. Oncol Rep. 2018;39(1):3-12.

9. Ishida Y, Otsuka A, Kabashima K. Cutaneous angiosarcoma: update on biology and latest treatment. Curr Opin Oncol. 2018;30(2):107-12.

10. Shustef E, Kazlouskaya V, Prieto VG, Ivan D, Aung PP. Cutaneous angiosarcoma: a current update. J Clin Pathol. 2017;70(11):917-25.

11. Oashi K, Namikawa K, Tsutsumida A, Takahashi A, Itami J, Igaki H, Inaba K, Yamazaki N. Surgery with curative intent is associated with prolonged survival in patients with cutaneous angiosarcoma of the scalp and face -a retrospective study of 38 untreated cases in the Japanese population. Eur J Surg Oncol. 2018:44(6):823-9.

12. Harati K, Kolbenschlag J, Bohm J, Niggemann H, Joneidi-Jafari H, Stricker I, Lehnhardt M, Daigeler A. Long-term outcomes of patients with soft tissue sarcoma of the chest wall: analysis of the prognostic significance of microscopic margins. Oncol Lett. 2018;15(2):2179-87.

13. Honda Y, Otsuka A, Ono S, Yamamoto Y, Seidel JA, Morita S, Hirata M, Kataoka TR, Takenouchi T, Fujii K, Kanekura T, Okubo Y, Takahashi K, Yanagi T, Hoshina D, Hata H, Abe R, Fujimura T, Funakoshi T, Yoshino K, Masuzawa M, Amoh Y, Tanaka R, Fujisawa Y, Honda T, Kabashima K. Infiltration of PD-1positive cells in combination with tumor site PD-L1 expression is a positive prognostic factor in cutaneous angiosarcoma. Oncoimmunology. 2016;6(1): e1253657.

14. Groesser $L$, Peterhof E, Evert M, Landthaler M, Berneburg M, Hafner C. BRAF and RAS mutations in sporadic and secondary pyogenic granuloma. J Invest Dermatol. 2016;136(2):481-6.

15. King RL, Pasha T, Roullet MR, Zhang PJ, Bagg A. IMP-3 is differentially expressed in normal and neoplastic lymphoid tissue. Hum Pathol. 2009; 40(12):1699-705.

16. Stoskus M, Gineikiene E, Valceckiene V, Valatkaite B, Pileckyte R, Griskevicius L. Identification of characteristic IGF2BP expression patterns in distinct B-ALL entities. Blood Cells Mol Dis. 2011;46(4):321-6.

17. Hartmann EM, Beà S, Navarro A, Trapp V, Campo E, Ott G, Rosenwald A. Increased tumor cell proliferation in mantle cell lymphoma is associated with elevated insulin-like growth factor 2 mRNA-binding protein 3 expression. Mod Pathol. 2012;25(9):1227-35.

18. Palanichamy JK, Tran TM, Howard JM, Contreras JR, Fernando TR, SterneWeiler T, Katzman S, Toloue M, Yan W, Basso G, Pigazzi M, Sanford JR, Rao DS. RNA-binding protein IGF2BP3 targeting of oncogenic transcripts promotes hematopoietic progenitor proliferation. J Clin Invest. 2016;126(4): 1495-511.

19. Li W, Liu D, Chang W, Lu X, Wang YL, Wang H, Zhu C, Lin HY, Zhang Y, Zhou J, Wang H. Role of IGF2BP3 in trophoblast cell invasion and migration. Cell Death Dis. 2014;5:e1025.

20. Sheen YS, Liao YH, Lin MH, Chu CY, Ho BY, Hsieh MC, Chen PC, Cha ST, Jeng YM, Chang CC, Chiu HC, Jee SH, Kuo ML, Chu CY. IMP-3 promotes migration and invasion of melanoma cells by modulating the expression of HMGA2 and predicts poor prognosis in melanoma. J Invest Dermatol. 2015; 135(4):1065-73.

21. Lan J, Huang B, Liu R, Ju X, Zhou Y, Jiang J, Liang W, Shen Y, Li F, Pang L. Expression of cancer stem cell markers and their correlation with pathogenesis in vascular tumors. Int J Clin Exp Pathol. 2015;8(10):12621-33.

\section{Publisher's Note}

Springer Nature remains neutral with regard to jurisdictional claims in published maps and institutional affiliations.

Ready to submit your research? Choose BMC and benefit from:

- fast, convenient online submission

- thorough peer review by experienced researchers in your field

- rapid publication on acceptance

- support for research data, including large and complex data types

- gold Open Access which fosters wider collaboration and increased citations

- maximum visibility for your research: over $100 \mathrm{M}$ website views per year

At $\mathrm{BMC}$, research is always in progress.

Learn more biomedcentral.com/submissions 